\title{
An analysis of African e-Government service websites ${ }^{2}$
}

\author{
Abebe Rorissa $^{a}, *$, Dawit Demissie ${ }^{b}$ \\ a Department of Information Studies, University at Albany, State University of New York, Draper Hall, Room 113, 135 Western Avenue, Albany, NY 12222, USA \\ b Department of Informatics, University at Albany, State University of New York, 7A Harriman Campus, Suite 220, 1400 Washington Avenue, Albany, NY 12222, USA
}

\section{A R T I C L E I N F O}

Available online $\mathrm{xxxx}$

\section{Keywords:}

Electronic government

e-Government

Africa

\begin{abstract}
A B S T R A C T
In most African countries, compared to any other part of the world, the use of information and communication technologies such as those necessary to provide e-Government services is minimal. The continent was once labeled a "technological desert." The contributing factors, among others, are lack of infrastructure, low literacy rates, low economic development, and a variety of cultural factors. Despite these obstacles, most African countries have made noticeable progress during the last couple of decades. Almost all African governments now have some presence on the Web, including fully fledged e-Government web portals, albeit in small numbers. However, the current status of e-Government services in African countries is not well documented in detail. We present results of a comprehensive analysis of $582 \mathrm{e}$-Government service websites with respect to the type of websites, the services and features available, as well as the level of development of e-Government services. We also compute e-Government indexes, produce e-Government rankings, and compare our rankings to previous ones. A clear picture that emerges from our analysis and results is that although progress has been made, there is a long way to go, to bridge not only the North-South divide when it comes to e-Government services but also among the various sub-regions. In addition, recommendations for future researchers regarding e-Government services in Africa are made.
\end{abstract}

Published by Elsevier Inc.

\section{Introduction}

Africa is the second largest continent with about a fifth of the world's total land area and the second most populous continent with one seventh (about 950 million) of the world's population. The continent (sub-Saharan Africa, in particular) was once labeled a "technological desert" with respect to technology adoption and use (Odedra, Lawrie, Bennett, \& Goodman, 1993). Since the early 1990s, electronic networks and other information and communication technologies have evolved slowly. The internet penetration rate stands at 5.3\% of the 950 million people who live on the continent, a $1030.2 \%$ growth over the last eight years (2000-2008) (Internet World Stats, 2009). Today, all African governments at some level (local, state, or national/federal) have implemented e-Government services. These range from static web pages to fully fledged portals that are one-stop gateways for services by all, or most, government agencies.

Not only are developing countries using information and communication technologies for governance in innovative ways, but the developmental opportunities presented as a result of the introduction

\footnotetext{
This is a revised and extended version of the paper "The state of the art of egovernment services in Africa: An analysis of relevant websites" which the authors presented at the 42nd Annual Hawaii International Conference on System Sciences (HICSS 2009), January 5-8, 2009, Waikoloa, Hawaii.

* Corresponding author.

E-mail address: arorissa@albany.edu (A. Rorissa).
}

of e-Government services to all kinds of communities (rural and urban) in these countries are tremendous (InfoDev, 2002). This is not to say that there are no obstacles. The slow diffusion and implementation of e-Government services on the African continent are attributable to a number of obstacles. Among those mentioned most often, especially in sub-Saharan Africa (with the exception of South Africa and a few others), are the lack of infrastructure, low literacy rates, slow and low economic development, and a variety of cultural factors. However, in spite of these obstacles, e-Government has arrived in Africa within the last decade or two (Heeks, 2002).

Even though e-Government has more than arrived in Africa, the current status of e-Government services in countries on the continent is not well-documented. Apart from a few authors who focused their investigations of e-Government services on Africa in general, or on certain African countries, in particular (e.g., Chango, 2007; Heeks, 2002; Mwangi, 2006), and a few others (e.g., United Nations, 2003, 2004, 2005, 2008; West, 2004, 2007) who included Africa in their general studies, existing e-Government literature focuses mainly on the U.S. and Europe (e.g., Lee, Tan, \& Trimi, 2005; Olphert \& Damodaran, 2007). As Schuppan (2009) noted, "only a few scholarly articles addressing E-Government in developing countries exist and... more commonly, this subject is discussed in the policy and strategy papers of various donor organizations, such as in the framework of the 2000 UN Millennium Development Goals" (p. 1). In addition, previous literature tends to perceive Africa as a single, homogeneous, and monolithic entity for the purposes of the study of e-Government initiatives (Heeks, 2002). This should not be the case, because the 
impact of information technology initiatives (such as e-Government) is greater in the least-developed countries, the majority of which are African countries (Heeks, 2002). This work attempts to fill the gap in the literature of e-Government services in Africa by describing the current status of e-Government services in Africa through analysis of 582 relevant e-Government service websites with respect to the type of e-Government websites and services they provide, the features available through the websites, as well as the level of development of e-Government service for each country. A website is selected if it provides e-Government related services and is maintained by a government entity. Not included are websites maintained by individuals and those that are not affiliated with any recognizable government body. Computations of e-Government indexes to produce e-Government rankings and comparisons to previous rankings are also included.

\section{Background}

Developing countries, such as those in Africa, are among the last to adopt the necessary technologies in order to provide e-Government services. The rate of adoption is slow due to several factors. Some of these include infrastructure, literacy, economic development, and culture. In spite of these obstacles, slight progress has been made over the last decade. Most African regions, with the exception of Southern and Northern Africa, have been found to lack the fundamental infrastructure, resources, and basic administrative organizations for eGovernment. These problems collectively resulted in what Gebremichael and Jackson (2006) called "information poverty." They argue that information poverty "is part of a larger pattern of social ailments. Its root causes have been theorized by many to be tied to information illiteracy, a lack of resources, governmental censorship and control, established information policies or lack thereof, and internal information infrastructures that lag behind the industrialized West" (Gebremichael \& Jackson, 2006, p. 2).

An important factor for the adoption of e-Government services, apart from the level of information \& communication technology (ICT) diffusion, is the political environment and national policies. More specifically, whether a government is open to political reform or not is among the determining factors (Lee, Tan, \& Trimi, 2005). For most countries in the world, including African nations, the implementation of e-Government and its associated ICT polices have been high priority issues (Carter \& May, 2001; Gillwald, Esselaar, Burton, \& Stavrou, 2005). It is true that there are multifaceted problems currently facing Africa as a continent. A closer examination of the attitude and previous record of African governments with respect to political reform paints a gloomy picture. However, there have been a number of ICT policy initiatives undertaken by various African countries, as well as regional and international organizations. Most African nations are determined to have e-Government services and to put in place the necessary and associated ICT polices (Maumbe, Owei, \& Alexander, 2008). These polices have partly laid the foundations for the development and implementation of e-Government services and websites.

In addition to these policies, several actions and programs by national and international organizations have assisted the development of e-Government services in Africa. Chief among these were the United Nations Economic Commission for Africa (UNECA), through the ICTs and Science \& Technology Division (ISTD) and its predecessor, the Pan African Development Information System (PADIS), and two of their flagship programs, the Capacity Building for Electronic Communication in Africa (CABECA) and the African Information Society Initiative (AISI). Through these programs, UNECA has advocated for capacity building through education and training in ICT and other areas and continues to do the same.

There is no doubt about the role information and communication technologies, including e-Government, has played and will continue to play in the development of a country, region, or continent, especially one as underdeveloped as Africa, where the impact of ICT and e-Government will even be greater. This point has been stressed by a number of authors since the introduction of ICTs, more specifically the internet, in Africa (e.g., Adam, 1997; Adam \& Wood, 1999). In order to gauge the impact of ICTs, in general, and e-Government services, in particular, baseline data and an understanding of the current status of their adoption and use are crucial. This work provides such baseline data by describing, in some detail, the status of e-Government services as reflected in the contents of African e-Government websites. At the very least, the data and results of the analyses and similar works could be used as one of the factors in determining winners of the Technology in Government in Africa (TIGA) Awards and incorporated into the criteria to be used in future awards.

\section{Methods}

\section{1. e-Government websites}

Results of this study, including computation of e-Government indexes and e-Government ranking of African countries, were based on the content analysis of 582 relevant e-Government websites for 53 African countries. An initial set of websites was obtained from a list compiled by Anzinger (2003) and then significantly updated. A search was conducted for additional websites in order to have a complete and updated list of the relevant websites. The review and coding of the contents of the e-Government websites were conducted during the months between December 2008 and May 2009. Despite efforts to have a comprehensive list, not every possible relevant website is included, due to the fact that some websites had URLs that did not work or links were broken.

\subsection{Data analysis}

Individual websites were the units of analysis. Out of a total of 1008 websites, subsequent analyses were conducted on 582 (57.7\%), an average of about 11 per country. A number of these $(34.8 \%$ of the 582) were in languages other than English. While the content analyses of the websites in Arabic and Portuguese were conducted with the help of two native speakers of the two languages, all the other websites, mainly in French, were first translated to English using the Google translation facility (http://translate.google.com/ translate_t?hl=en) and then content analyzed. The content analysis was conducted to identify the type of site or body/institution responsible for its contents and services, the type of services, the features available on the website, and the number of executable services available through the website, as well as the level of development of e-Government services.

As part of the analysis, a four-stage framework of levels/stages of development of e-Government services was used (Affisco \& Soliman, 2006; Al-adawi, Yousafzai, \& Pallister, 2005). The four-stage framework was decided upon after a review of other frameworks with four stages (e.g., Layne \& Lee, 2001) and some with five stages (e.g., Moon, 2002; Torres, Pina, \& Acerete, 2005; UNDPEPA, 2002; and United Nations, 2008) because even the five stages map to the four stages in the framework selected. Generally, irrespective of the framework, the technological and organizational complexities, as well as integration of services and functions, increase as the websites move from a lower level/stage to a higher one. According to Affisco and Soliman (2006) \& Al-adawi, Yousafzai, and Pallister (2005), there are four stages/levels of development of e-Government services, namely (1) publishing (web presence), (2) interacting, (3) transacting, and (4) transforming (integration). There is a marked difference between an e-Government website that provides only static information and another one that allows online interaction and transaction, as well as serving as a one- 
stop shop or gateway to most e-Government services. A website at the first (publishing) level presents static information about the government agency, whereas a website at the second (interacting) level allows the downloading of forms (for completion offline) and provides search functions. An e-Government website at the third (transacting) level allows the completion of an entire task online without requiring citizens to travel to the relevant offices. A website at the fourth, and last (transforming) level, is usually a single-point portal that integrates all e-Government services by a number of branches of government at all levels.

A graduate student, who was unaware of the purposes of the study, coded a random sample of 116 (about 20\%) of all the websites. Percent agreement and Cohen's (1960) kappa, two popular measures of intercoder agreement, were used to measure the consistency or reliability of the coding between one of the authors who coded all the websites and the graduate student. The computed percent agreement and kappa values are presented in Table 1. It is clear from the table that all the values are at or above the recommended threshold of intercoder agreement and kappa values, which is usually 0.70 (Neuendorf, 2002).

Among the procedures and frameworks currently used by researchers for e-Government index computation and ranking, West's (2007) method of computing e-Government index was chosen because it uses an objective set of procedures, and it is entirely based on contents of relevant e-Government service websites. West (2007) follows a two-stage process of computing an index for each website first and then averages them across all websites to compute a single index for each country (a value between 0 and 100). For each of the 18 features (publications, databases, audio clips, video clips, foreign language access, not having ads, not having premium fees, not having user fees, disability access, having privacy policies, security policies, allowing digital signatures on transactions, an option to pay via credit cards, email contact information, areas to post comments, option for email updates, option for website personalization, PDA (personal digital assistant) accessibility), West (2007) awarded four points to a website and added the total points (up to a maximum of 72 ) for the features to the total number of online executable services (up to a maximum of 28 points). Online executable services allow users to complete transactions online without physically visiting service centers (e.g., renewing drivers' licenses). Eqs. (1) and (2) below describe West's (2007) procedures.

$\mathrm{e}-$ Government index for site $i, e_{i}=4 f_{i}+x_{i}$

where,

$f_{i}=$ the number of features present on website $i, 0 \leq f_{i} \leq 18$

$x_{i}=$ the number of online executable services on website $i$, $0 \leq x_{i} \leq 28$

$\mathrm{e}-$ Government index country $\mathrm{j}, E_{j}=\frac{\sum_{i=1}^{n} e_{i}}{n}$

Table 1

Values of measures of the consistency or reliability of the coding.

\begin{tabular}{lll}
\hline What was coded & Percent agreement & Kappa \\
\hline $\begin{array}{l}\text { Type of website or body/institution responsible for } \\
\text { its contents }\end{array}$ & 0.87 & 0.74 \\
$\begin{array}{l}\text { Type of services available through the website } \\
\text { Type of features available on the website }\end{array}$ & 0.75 & 0.70 \\
$\quad \begin{array}{l}\text { Number of executable services available through } \\
\text { the website }\end{array}$ & 0.86 & 0.70 \\
Level of development of e-Government services & 0.89 & 0.72 \\
\hline
\end{tabular}

where,

$e_{i}=$ e-government index for website i, $0 \leq e_{i} \leq 100$

$n=$ total number of websites for country $j, n \geq 1$

For instance, to compute the e-Government index for a country with three (3) e-Government websites where each of them have 14,19, and 17 features and 8, 6, and 7 online executable services, respectively, the first step is computing e-Government index for each website:

e-Government index for website $1: e_{1}=4(14)+8=64$

e-Government index for website $2: e_{2}=4(19)+6=82$

e-Government index for website $3: e_{3}=4(17)+7=75$

The second (and last) step is computing e-Government index for the country: $\mathrm{e}$-Government index for the country, $E_{1}=\frac{\sum_{i=1}^{3} e_{i}}{3}=\frac{64+82+75}{3}=\frac{221}{3}=73.67$

\section{Results}

\subsection{Description of e-Government websites and services}

\subsubsection{Type of website}

Among the 582 e-Government websites, there were far more federal/national government and federal/national government department websites (58.93\%), as well as websites for embassies of federal/national governments (16.15\%), than local government and local government department websites (2.75\%). Unlike encouraging signs of e-Government readiness and implementation at the national or federal levels, there is hardly any web presence for local governments in most African countries. This is in keeping with common trends in most countries around the world (except for countries such as the United Kingdom), even though the situation is fast improving in some countries. Even for the developed countries, eGovernment service websites were first created and maintained by institutions at the national or federal level. They took the top down approach, where there are more e-Government services at the national level than the local level. This puts users of services by local governments at a disadvantage because, as the analysis below indicates, there is little or no vertical integration when it comes to e-Government services, and there are hardly any portals in most African countries. While e-Government services are equally important at national and local levels, they are even more important and beneficial to citizens if there is a vertical integration between the two levels (Table 2).

\subsubsection{Type of service}

e-Government services have a dual purpose: for the government to dispense its public duties and responsibilities, as well as to provide automation services in an effective and efficient manner. The central focus of any e-Government website should be the number and quality of services available to the ordinary citizen. That the number of African e-Government service websites providing form and document download service is large (57.19\%) is not surprising, given the fact that these are among the first services available through most e-Government websites, even those at the initial stages of e-Government service development. The minimum and median number of websites per country that provide most of the 13 services (Table 3 ) is zero, an indication of the unavailability of most of these services through African e-Government service websites. That is why over half of these websites (52.92\%) have the lowest e-Government service development level of 1 (see Table 6). It was disappointing to see that in spite of a fair number of e-Government websites maintained by embassies of African governments (16.15\%), and despite the fact that a significant number of 
Table 2

Type of website in terms of the body/institution responsible for its contents.

\begin{tabular}{|c|c|c|c|c|c|c|c|c|c|c|c|c|c|}
\hline \multirow[t]{2}{*}{ Country } & \multicolumn{6}{|c|}{ Number of websites by } & \multirow[t]{2}{*}{ Country } & \multicolumn{6}{|c|}{ Number of websites by } \\
\hline & 1 & 2 & 3 & 4 & 5 & 6 & & 1 & 2 & 3 & 4 & 5 & 6 \\
\hline Algeria & 6 & 0 & 12 & 0 & 8 & 3 & Libya & 1 & 0 & 0 & 0 & 0 & 2 \\
\hline Angola & 1 & 0 & 1 & 0 & 5 & 2 & Madagascar & 2 & 0 & 5 & 0 & 1 & 2 \\
\hline Benin & 2 & 0 & 6 & 0 & 1 & 0 & Malawi & 2 & 0 & 5 & 0 & 2 & 0 \\
\hline Botswana & 3 & 0 & 6 & 0 & 1 & 0 & Mali & 0 & 0 & 4 & 0 & 0 & 1 \\
\hline Burkina Faso & 1 & 1 & 7 & 0 & 2 & 1 & Mauritania & 2 & 0 & 1 & 0 & 0 & 0 \\
\hline Burundi & 0 & 0 & 1 & 0 & 0 & 2 & Mauritius & 0 & 1 & 7 & 0 & 4 & 5 \\
\hline Cameroon & 3 & 0 & 6 & 0 & 2 & 5 & Morocco & 2 & 0 & 10 & 0 & 4 & 5 \\
\hline Cape Verde & 2 & 0 & 2 & 0 & 1 & 4 & Mozambique & 2 & 0 & 4 & 0 & 2 & 2 \\
\hline Central African Republic & 0 & 0 & 0 & 0 & 1 & 2 & Namibia & 3 & 1 & 9 & 0 & 2 & 1 \\
\hline Chad & 0 & 0 & 0 & 0 & 0 & 3 & Niger & 0 & 0 & 1 & 0 & 1 & 0 \\
\hline Comoros & 2 & 0 & 0 & 0 & 1 & 2 & Nigeria & 1 & 3 & 5 & 0 & 6 & 2 \\
\hline Congo & 2 & 0 & 0 & 0 & 2 & 3 & Rwanda & 2 & 0 & 3 & 0 & 1 & 5 \\
\hline Congo (DR) & 2 & 0 & 0 & 0 & 0 & 1 & São Tomé and Príncipe & 1 & 0 & 0 & 0 & 1 & 0 \\
\hline Djibouti & 1 & 0 & 5 & 0 & 0 & 1 & Senegal & 0 & 1 & 6 & 0 & 5 & 2 \\
\hline Egypt & 2 & 0 & 15 & 0 & 4 & 4 & Seychelles & 2 & 0 & 6 & 1 & 0 & 4 \\
\hline Equatorial Guinea & 1 & 0 & 0 & 0 & 0 & 0 & Sierra Leone & 1 & 0 & 0 & 0 & 1 & 7 \\
\hline Eritrea & 1 & 0 & 1 & 0 & 0 & 0 & Somalia & 0 & 0 & 0 & 0 & 0 & 2 \\
\hline Ethiopia & 0 & 0 & 7 & 0 & 7 & 7 & South Africa & 2 & 3 & 44 & 5 & 8 & 13 \\
\hline Gabon & 3 & 0 & 1 & 0 & 1 & 0 & Sudan & 0 & 0 & 0 & 0 & 3 & 7 \\
\hline Gambia & 2 & 0 & 5 & 0 & 0 & 2 & Swaziland & 4 & 0 & 1 & 0 & 1 & 2 \\
\hline Ghana & 1 & 0 & 10 & 0 & 6 & 3 & Tanzania & 1 & 0 & 9 & 0 & 0 & 1 \\
\hline Guinea & 0 & 0 & 6 & 0 & 0 & 0 & Togo & 0 & 0 & 1 & 0 & 0 & 1 \\
\hline Guinea-Bissau & 0 & 0 & 1 & 0 & 1 & 1 & Tunisia & 1 & 0 & 10 & 0 & 0 & 4 \\
\hline Ivory Coast & 0 & 0 & 0 & 0 & 1 & 3 & Uganda & 1 & 0 & 13 & 0 & 1 & 4 \\
\hline Kenya & 1 & 0 & 21 & 0 & 3 & 3 & Zambia & 0 & 0 & 9 & 0 & 0 & 1 \\
\hline Lesotho & 1 & 0 & 7 & 0 & 2 & 0 & Zimbabwe & 1 & 0 & 2 & 0 & 0 & 4 \\
\hline Liberia & 0 & 0 & 0 & 0 & 2 & 0 & Total & 68 & 10 & 275 & 6 & 94 & 129 \\
\hline
\end{tabular}

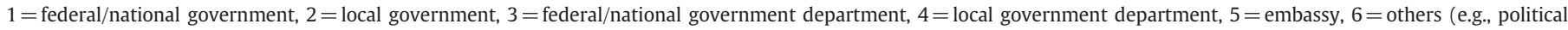
parties, etc.).

African economies are dependent on tourism, only $0.45 \%$ of the websites provide online visa application services.

\subsubsection{Features}

One of the two major component parts of the current frameworks and procedures for the computation of e-Government indexes and rankings is the number of features present on an e-Government service website. The top five countries in terms of the number of features available on their e-Government websites are South Africa (460), Algeria (189), Egypt (161), Kenya (140), and Morocco (131). However, the top five countries in terms of the mean number of features available on their e-Government websites are Togo (8.00), Eritrea (7.00), Tunisia (6.93), Libya (6.67), and Mauritius (6.53). In theory, the higher the number of features, the higher the e-Government index for a website. Eventually, the more such

Table 3

Number of websites that deliver the different types of e-Government services $(n=53)$.

\begin{tabular}{llrrrrr}
\hline \multirow{2}{*}{ Type of service } & \multicolumn{7}{l}{ Number of websites } \\
\cline { 2 - 7 } & Min & Max & Mean & SD & Total & \multicolumn{1}{l}{} \\
\hline Tax filing & 0 & 6 & 0.49 & 1.23 & 26 & 2.94 \\
Voter registration & 0 & 4 & 0.19 & 0.65 & 10 & 1.13 \\
Application and renewal of passport & 0 & 4 & 0.11 & 0.58 & 6 & 0.68 \\
Job listing and/or application & 0 & 32 & 1.58 & 4.55 & 84 & 9.51 \\
Visa application & 0 & 2 & 0.08 & 0.33 & 4 & 0.45 \\
Complaint submission & 0 & 4 & 0.19 & 0.62 & 10 & 1.13 \\
Application and renewal of & 0 & 1 & 0.04 & 0.19 & 2 & 0.23 \\
$\quad$ driver's license & & & & & & \\
Application and renewal of & 0 & 1 & 0.08 & 0.27 & 4 & 0.45 \\
$\quad$ business licenses & & & & & & \\
Order reports and other documents & 0 & 6 & 0.28 & 1.03 & 15 & 1.70 \\
Grant application & 0 & 0 & 0.00 & 0.00 & 0 & 0.00 \\
Application for benefits & 0 & 3 & 0.06 & 0.41 & 3 & 0.34 \\
Document and trademark filing & 0 & 0 & 0.00 & 0.00 & 0 & 0.00 \\
Download forms and other documents & 1 & 60 & 9.53 & 9.52 & 505 & 57.19 \\
Others (e.g., webmail) & 0 & 46 & 4.04 & 7.25 & 214 & 24.24 \\
Total & & & & & $883^{\mathrm{a}}$ & 100.00 \\
\hline
\end{tabular}

a Total exceeds 582 because some websites provide more than one service. websites there are, the higher the e-Government index should be for the country (computed using West's (2007) framework). However, this is not always the case (see Table 7).

The more prominent features on e-Government websites for African governments are "not having premium fees", "not having user fees", "not having ads", "email contact information", and "publications" which, when combined, account for $81.43 \%$ of the features on all the 582 websites (Table 4). Once again, given the low literacy rates in most of these countries, and their need to promote tourism potential and industry, a much higher number of websites should have had either audio $(0.92 \%)$ or video $(1.10 \%)$ clips or both $(2.02 \%$ only) as one of their main features.

Table 4

Type of features present on the websites $(n=53)$.

\begin{tabular}{llrrrrr}
\hline \multirow{2}{*}{ Type of feature } & \multicolumn{7}{l}{ Number of websites } & & \\
\cline { 2 - 7 } & Min & Max & Mean & SD & Total & \multicolumn{1}{c}{$\%$} \\
\hline Publications & 0 & 58 & 8.06 & 9.13 & 427 & 13.08 \\
Databases & 0 & 5 & 0.64 & 1.13 & 34 & 1.04 \\
Audio clips & 0 & 9 & 0.57 & 1.39 & 30 & 0.92 \\
Video clips & 0 & 8 & 0.68 & 1.59 & 36 & 1.10 \\
Foreign language access & 0 & 29 & 4.64 & 5.85 & 246 & 7.54 \\
Not having ads & 0 & 73 & 10.68 & 11.18 & 566 & 17.34 \\
Not having premium fees & 0 & 75 & 10.87 & 11.45 & 576 & 17.65 \\
Not having user fees & 0 & 75 & 10.79 & 11.43 & 572 & 17.52 \\
Disability access & 0 & 1 & 0.04 & 0.19 & 2 & 0.06 \\
Having privacy policies & 0 & 17 & 0.60 & 2.40 & 32 & 0.98 \\
Security policies & 0 & 1 & 0.02 & 0.14 & 1 & 0.03 \\
Allowing digital signatures & 0 & 1 & 0.02 & 0.14 & 1 & 0.03 \\
$\quad$ on transactions & & & & & & \\
An option to pay via credit cards & 0 & 6 & 0.83 & 1.10 & 44 & 1.35 \\
Email contact information & 1 & 71 & 9.32 & 10.88 & 494 & 15.13 \\
Areas to post comments & 0 & 36 & 2.17 & 5.24 & 115 & 3.52 \\
Option for email updates & 0 & 23 & 1.58 & 3.47 & 84 & 2.57 \\
Option for website personalization & 0 & 1 & 0.04 & 0.19 & 2 & 0.06 \\
PDA accessibility & 0 & 1 & 0.04 & 0.19 & 2 & 0.06 \\
Total & & & & & $3264^{\mathrm{a}}$ & 100.00 \\
\hline Total exceds & & & & & & \\
\hline
\end{tabular}

a Total exceeds 582 because some websites have more than one feature. 
Table 5

Frequency and mean number of online executable services.

\begin{tabular}{|c|c|c|c|c|c|c|c|}
\hline Country & $\begin{array}{l}\text { No. of executable } \\
\text { services }\left(x_{i}\right)\end{array}$ & No. of sites & Mean $\left(x_{i}\right)$ & Country & $\begin{array}{l}\text { No. of executable services } \\
\left(x_{i}\right) \# \text { of Exec. Services }\left(x_{i}\right)\end{array}$ & No. of sites & Mean $\left(x_{i}\right)$ \\
\hline Algeria & 3 & 29 & 0.10 & Libya & 0 & 3 & 0.00 \\
\hline Angola & 1 & 9 & 0.11 & Madagascar & 3 & 10 & 0.30 \\
\hline Benin & 4 & 9 & 0.44 & Malawi & 1 & 9 & 0.11 \\
\hline Botswana & 3 & 10 & 0.30 & Mali & 2 & 5 & 0.40 \\
\hline Burkina Faso & 3 & 12 & 0.25 & Mauritania & 2 & 3 & 0.67 \\
\hline Burundi & 1 & 3 & 0.33 & Mauritius & 15 & 17 & 0.88 \\
\hline Cameroon & 6 & 16 & 0.38 & Morocco & 22 & 21 & 1.05 \\
\hline Cape Verde & 1 & 9 & 0.11 & Mozambique & 5 & 10 & 0.50 \\
\hline Central African Republic & 0 & 3 & 0.00 & Namibia & 5 & 16 & 0.31 \\
\hline Chad & 0 & 3 & 0.00 & Niger & 0 & 2 & 0.00 \\
\hline Comoros & 0 & 5 & 0.00 & Nigeria & 8 & 17 & 0.47 \\
\hline Congo & 1 & 7 & 0.14 & Rwanda & 1 & 11 & 0.09 \\
\hline Congo (DR) & 1 & 3 & 0.33 & São Tomé and Príncipe & 0 & 2 & 0.00 \\
\hline Djibouti & 4 & 7 & 0.57 & Senegal & 0 & 14 & 0.00 \\
\hline Egypt & 57 & 25 & 2.28 & Seychelles & 7 & 13 & 0.54 \\
\hline Equatorial Guinea & 0 & 1 & 0.00 & Sierra Leone & 1 & 9 & 0.11 \\
\hline Eritrea & 0 & 2 & 0.00 & Somalia & 0 & 2 & 0.00 \\
\hline Ethiopia & 2 & 21 & 0.10 & South Africa & 144 & 75 & 1.92 \\
\hline Gabon & 1 & 5 & 0.20 & Sudan & 0 & 10 & 0.00 \\
\hline Gambia & 3 & 9 & 0.33 & Swaziland & 2 & 8 & 0.25 \\
\hline Ghana & 1 & 20 & 0.05 & Tanzania & 5 & 11 & 0.45 \\
\hline Guinea & 0 & 6 & 0.00 & Togo & 0 & 2 & 0.00 \\
\hline Guinea-Bissau & 0 & 3 & 0.00 & Tunisia & 19 & 15 & 1.27 \\
\hline Ivory Coast & 0 & 4 & 0.00 & Uganda & 12 & 19 & 0.63 \\
\hline Kenya & 4 & 28 & 0.14 & Zambia & 2 & 10 & 0.20 \\
\hline Lesotho & 5 & 10 & 0.50 & Zimbabwe & 3 & 7 & 0.43 \\
\hline Liberia & 0 & 2 & 0.00 & Total & 360 & 582 & 0.62 \\
\hline
\end{tabular}

\subsubsection{Online executable services}

The second major component of the current frameworks and procedures for the computation of e-Government indexes and rankings (in addition to the number of features) is the number of online executable services. A country's e-Government ranking is either higher or lower to the extent that the mean number of features and online executable services available through its e-Government service websites is higher or lower. The total number of online executable services for all the websites was 360 , that is an average of 0.618 online executable services per website. Of the 582 e-Government websites, a significant number of them, 518 (89\%), provide one or more online executable services (see Table 5).

The top five countries in terms of mean number of online executable services are Egypt (2.28), South Africa (1.92), Tunisia (1.27), Morocco (1.05), and Mauritius (0.88), while the order (from first to last) in terms of the absolute number of online executable services is South Africa (144), Egypt (57), Morocco (22), Tunisia (19), and Mauritius (15). Sixteen (30.18\%) of the countries provide no online executable service. Clearly, African governments need to increase the type of features and online executable services they make available on their e-Government websites, if they are to improve their standing relative to countries in other regions of the world with respect to e-Government ranking.

\subsubsection{Level/Stage}

From the users' point of view, an e-Government service website at the transforming (integration) level of development is much preferred to one at the lower levels. An example of such a website is a portal serving as a one-stop gateway to most e-Government services, which not only combines both horizontal integration (an integration of different functions and services) and vertical integration (an integration of local systems to higher-level systems and local governments to state and federal governments), but it also saves the user time, energy, effort, and many more resources. Unfortunately, almost all e-Government service websites by African governments (95.53\%) are either at the first (publishing or web presence) or second (interacting) stages of development. This should be expected because a large (57.19\%) number of African e-Government service websites provide only the first service often provided by most e-Government websites, the ability to download forms and documents, at the beginning of their introduction or implementation (Table 6).

\section{2. e-Government index and ranking}

Based on the analysis of the 582 e-Government service websites, the current e-Government index for each African country was computed and current rankings for 2008 produced (Table 7). Given the importance any benchmarking and ranking is given when devising policies and allocating resources to implement those policies by individual institutions and countries, an objective framework to produce the rankings is paramount. West's (2007) set of procedures to compute e-Government indexes for 53 African countries was followed in order to compare the rankings of these countries to the previous year's rankings. West's (2007) framework was chosen because it is based on objective measures of features and online executable services available via the websites. Table 7 presents these rankings and comparisons. According to West (2007), in 2007, the top five ranked countries in Africa in terms of e-Government services as reflected in the contents of e-Government websites were Equatorial Guinea, Liberia, Sierra Leone, Eritrea, and Ethiopia, only one of which was in the top five in 2008. The top five ranked countries in Africa with respect to e-Government services in 2008 were Togo, Tunisia, Egypt, Eritrea, and Mauritius. While three countries did not improve

Table 6

Number of websites at the four levels of e-Government service development $(n=53)$.

\begin{tabular}{lllllrr}
\hline \multirow{2}{*}{ Level } & \multicolumn{7}{l}{ Number of websites } \\
\cline { 2 - 7 } & Min & Max & Mean & SD & Total & \multicolumn{1}{c}{$\%$} \\
\hline 1. Publishing & 0 & 22 & 5.81 & 4.10 & 308 & 52.92 \\
2. Interacting & 0 & 60 & 4.68 & 8.79 & 248 & 42.61 \\
3. Transacting & 0 & 8 & 0.43 & 1.26 & 23 & 3.95 \\
4. Transforming & 0 & 2 & 0.06 & 0.30 & 3 & 0.52 \\
Total & & & & & 582 & 100 \\
\hline
\end{tabular}


Table 7

e-Government index and ranking of African countries (2007 and 2008).

\begin{tabular}{|c|c|c|c|c|c|c|c|c|c|c|c|}
\hline Country & 1 & 2 & $3^{a}$ & Country & 1 & 2 & $3^{*}$ & Country & 1 & 2 & $3^{a}$ \\
\hline Algeria & 26.1724 & 8 & 34 & Gabon & 24.2500 & 13 & 6 & Niger & 20.0000 & 39 & 46 \\
\hline Angola & 25.8889 & 10 & 21 & Gambia & 22.1111 & 24 & 22 & Nigeria & 23.7647 & 16 & 18 \\
\hline Benin & 23.5556 & 18 & 27 & Ghana & 19.2500 & 47 & 11 & Rwanda & 21.1818 & 29 & 43 \\
\hline Botswana & 20.3000 & 37 & 10 & Guinea & 22.0000 & 25 & 53 & São Tomé and Príncipe & 18.0000 & 51 & 47 \\
\hline Burkina Faso & 22.5833 & 23 & 48 & Guinea-Bissau & 20.0000 & 39 & 12 & Senegal & 23.7143 & 17 & 30 \\
\hline Burundi & 16.3333 & 52 & 38 & Ivory Coast & 20.0000 & 39 & 39 & Seychelles & 20.8462 & 33 & 33 \\
\hline Cameroon & 23.1250 & 22 & 45 & Kenya & 20.1429 & 38 & 14 & Sierra Leone & 18.3333 & 50 & 3 \\
\hline Cape Verde & 23.2222 & 21 & 16 & Lesotho & 19.3000 & 46 & 15 & Somalia & 14.0000 & 53 & 36 \\
\hline Central African Republic & 24.0000 & 15 & 49 & Liberia & 20.0000 & 39 & 2 & South Africa & 26.4533 & 7 & 24 \\
\hline Chad & 20.0000 & 39 & 41 & Libya & 26.6667 & 6 & 8 & Sudan & 18.8000 & 49 & 25 \\
\hline Comoros & 25.6000 & 11 & 52 & Madagascar & 20.7000 & 36 & 29 & Swaziland & 21.7500 & 27 & 9 \\
\hline Congo & 24.1667 & 14 & 17 & Malawi & 21.4444 & 28 & 40 & Tanzania & 23.3636 & 19 & 50 \\
\hline Congo (DR) & 24.5000 & 12 & 20 & Mali & 19.6000 & 45 & 35 & Togo & 32.0000 & 1 & 37 \\
\hline Djibouti & 21.1429 & 30 & 31 & Mauritania & 22.0000 & 25 & 51 & Tunisia & 29.0000 & 2 & 42 \\
\hline Egypt & 28.0400 & 3 & 13 & Mauritius & 27.0000 & 5 & 32 & Uganda & 20.8421 & 34 & 28 \\
\hline Equatorial Guinea & 20.0000 & 39 & 1 & Morocco & 26.0000 & 9 & 23 & Zambia & 21.0000 & 31 & 7 \\
\hline Eritrea & 28.0000 & 4 & 4 & Mozambique & 23.3000 & 20 & 19 & Zimbabwe & 21.0000 & 31 & 26 \\
\hline Ethiopia & 19.0000 & 48 & 5 & Namibia & 20.7647 & 35 & 44 & & & & \\
\hline
\end{tabular}

$1=$ current index (2008), 2 = current rank (2008), $3=2007$ rank (West, 2007).

a Rank was re-assigned with the highest ranked African country in West 's (2007) ranking receiving a rank of 1 . Note that the same set of procedures (due to West (2007)) was used to produce both rankings (2007 \& 2008).

their rankings in 2008 (that is, stayed the same in the ranking), 23 were lower and the remaining 27 were higher in the 2008 rankings than in the 2007 rankings. This disparity in the two rankings (2007 \& 2008) could partially be attributed to the type and number of e-Government websites considered to produce the rankings, even though the procedures used to compute the e-Government indexes were essentially the same. In addition, West's (2007) framework does not reward countries with more websites that have more number of features and online executable services.

\section{3. e-Government service websites across regions of Africa}

In order to compare the various sub-regions of the continent with respect to the type of site, type of service, feature, level/stage of

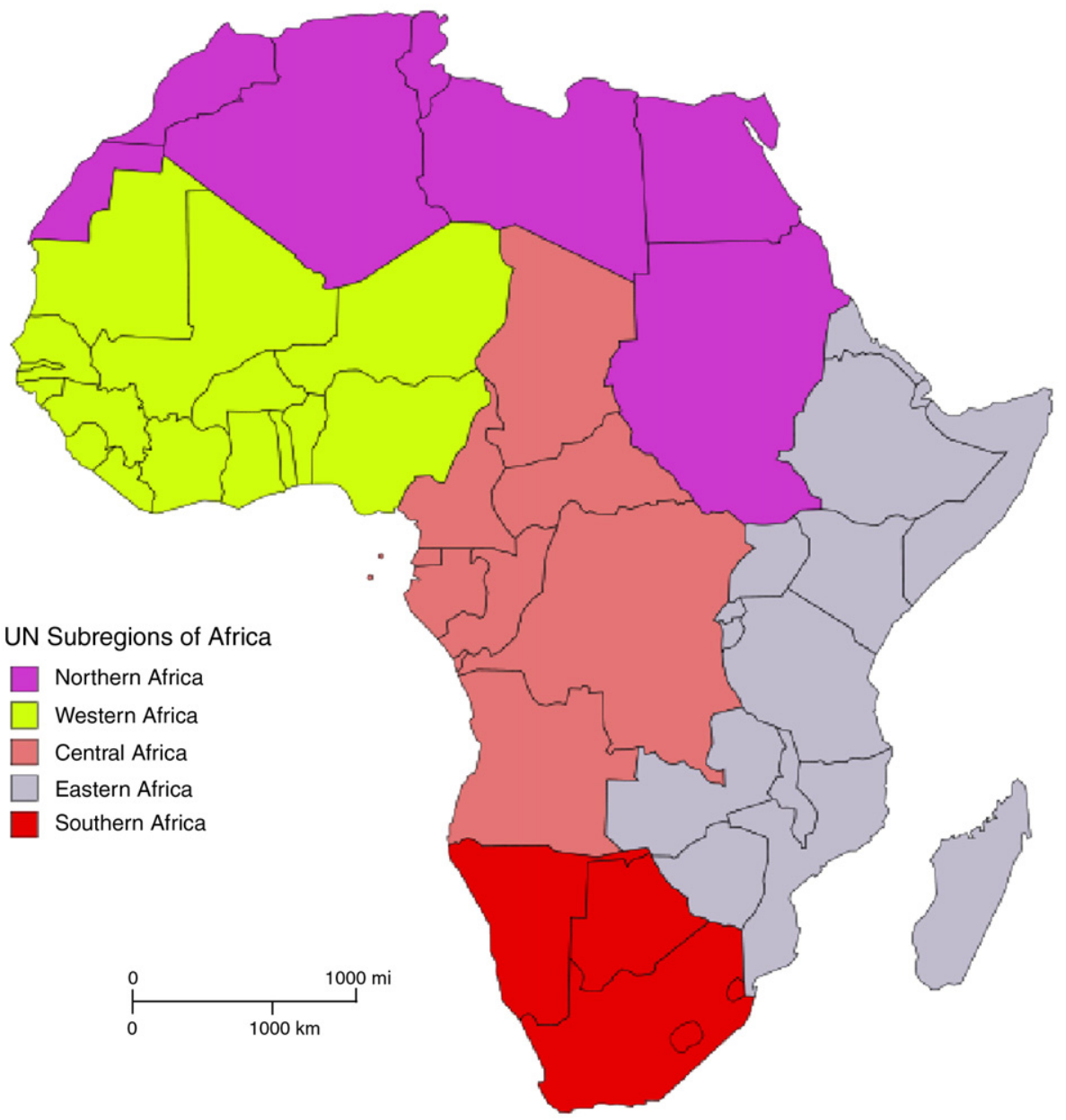

Fig. 1. Five sub-regions of Africa. 
Table 8

Comparison of the sub-regions of Africa with respect to the type of site, type of service, feature, level/stage of e-Government development, and online executable services.

\begin{tabular}{lccl}
\hline & Chi-square & df & $p$-value \\
\hline Type of site & $38.54^{*}$ & 12 & 0.000125 \\
Type of service & $56.03^{*}$ & 12 & 0.00 \\
Feature & $177.07^{*}$ & 48 & 0.00 \\
Level/Stage & $67.97^{*}$ & 4 & 0.00 \\
Executable services $^{\mathrm{a}}$ & $303.40^{*}$ & 4 & 0.00 \\
\hline
\end{tabular}

$* p<0.01$.

a In order to conduct the chi-square test, the range of the number of executable services was divided into two (0-72 and 73-145).

e-Government development, and online executable services on their eGovernment websites, the 53 countries were divided into the five subregions often used by the United Nations (Fig. 1). To assess the differences across sub-regions, a chi-square test of independence was conducted using the sub-regions (with five categories of Northern, Western, Central, Eastern, and Southern Africa) as the column variable. A few of the cells in the contingency tables had expected frequencies that were less than one and, in some cases, more than $20 \%$ of the cells had expected frequencies less than five, violating some of the assumptions of the chi-square test (Weinberg \& Goldberg, 1990). In such cases, more chi-square tests of independence were conducted by either combining or deleting categories that contributed to the violation of these assumptions. These actions did not affect the results, because similar results were obtained (in terms of significance of chi-square values).

The chi-square values in Table 8 clearly indicate that the five subregions of Africa are different with respect to the type of e-Government website (or body responsible for the contents of the websites), type of service, feature, level/stage of e-Government development, and online executable services. This is expected because the sub-regions vary in terms of the underlying conditions/factors for e-Government development, such as level of economic development, e-readiness, level of ICT adoption, and other factors. It is also one more reason not to consider the continent as a single, homogeneous, and monolithic entity for both research and practical purposes (Heeks, 2002). Africa is a more heterogeneous continent than its characterization, with a wide range of intra and inter country differences in terms of culture, infrastructure, literacy, colonial legacies, languages, geography, type of government, political structures/conditions, levels of economic development, culture, and other aspects.

\section{Summary, recommendations, and future work}

\subsection{Summary of results}

This study set out to conduct a comprehensive analysis of contents of African e-Government service websites. An initial list of 1008 websites was compiled and further scrutiny of the URLs (some of which were not available during analysis) reduced the number to 582. Africa was chosen because developing countries, in general, and African countries, in particular, are the last to adopt the necessary technologies for e-Government services, and little attention has been paid to the topic by previous literature. Despite apparent obstacles, over the last decade, African countries have made progress in terms of building the necessary infrastructure, designing policies, as well as developing and implementing e-Government services. In order to fully understand the contents of African e-Government service websites, a four-stage framework was used (Affisco \& Soliman, 2006; Al-adawi, Yousafzai, \& Pallister, 2005), a framework similar to the one proposed by Layne \& Lee (2001). West's (2007) framework for computing e-Government index was also used because of its less complex nature and the fact that it is based on objective measures of features and online executable services available via the e-Government service websites.
Even though there are encouraging signs of e-Government implementation at the national or federal levels, there is hardly any web presence for local governments in most African countries, a trend similar to that in most other countries around the world. Most African e-Government websites provide the basic service of form and document downloading while the majority of other important services are not available. As indicated, two of the major components of current frameworks and procedures for the computation of e-Government indexes and rankings are the number of features and online executable services present on e-Government service websites. Neither are significantly featured on most African e-Government websites. This will have a greater impact on their ranking relative to countries in other parts of the world. About a third of the e-Government websites provide no online executable services and an average of 0.618 online executable services are available per website. In terms of their level of development of e-Government services, almost all African e-Government service websites (95.53\%) are either at the first (publishing or web presence) or second (interacting) stages or levels of e-Government service development.

\subsection{Recommendations}

The dominant mode of interaction and communication as implemented through African e-Government websites is government-to-citizen (G2C). If Africa and other developing regions are to take advantage of the potential and opportunities presented by eGovernment and associated technologies, individual countries, as well as the continent as a whole as it strives to form an efficient union, need to consider implementation of government-to-business (G2B), government-to-government (G2G), government-to-employees (G2E), and other modes of interaction and communication.

In order to improve their electronic government services and succeed in the development and implementation of new fully fledged e-Government services and portals, African countries need to consider the fact that, in addition to technological factors, factors such as organizational structures and processes, institutional arrangements (e.g., laws, regulations, policies, and other constraints) and contextual factors (e.g., cultural, political, economic, demographic, and ecological conditions) have either direct or indirect effects on e-Government success (Gil-Garcia, 2005). What is more, they should note that the very institutions and cultures that stand to benefit from e-Government sometimes stand in the way of its diffusion. It has been previously confirmed that when governments champion the adoption of e-Government technologies, their success increases significantly (Ke \& Wei, 2004).

The role of government in the development and implementation of e-Government services, and other information and communication technologies for that matter, is bigger in African countries than in developed nations. In most African countries, large private enterprises that can run ICT based businesses are few (often as a result of restrictive/prohibitive policies) and/or the government controls much of the technologies and physical infrastructure on which e-Government services rely. e-Government services will be widely adopted and have maximum impact in developing nations, such as those in Africa, only if governments at all levels are willing to streamline their current service delivery mechanisms and structures. For instance, it is often the case that, in these countries, something as simple as obtaining a driver's license involves a visit (often physically) to several offices, departments, or agencies. An e-Government service, and any service for that matter, is most beneficial when there are as few service points as possible.

Another important action to boost e-readiness and the provision of e-Government services by African countries is sensitization. Organizations, such as the International Telecommunication Union (ITU), are doing their part in this regard. For instance, in 2007, the ITU organized 
a "Connect Africa Summit" (http://www.itu.int/ITU-D/connect/africa/ 2007/index.html) which was attended by high-ranking officials from relevant departments and ministries of all African countries, as well as multinational corporations, such as Intel and Microsoft.

An added advantage that developing countries, including those in Africa, have when it comes to e-Government services is that there are several success stories from which they can learn, thereby avoiding common pitfalls. The development and implementation of e-Government services, together with developments in other sectors, such as commerce, agriculture, technology, health, and education, will have a greater effect on the countries' overall development than if the countries were inactive while the rest of the world moves into the information age at full speed. If African countries fail to take advantage of the eGovernment phenomenon, there is a real chance that the economic and digital divide between them and the rest of the world, more specifically developed countries, will widen, and they may even be less competitive in the global economy than they are now (Heeks, 2002; Ifinedo, 2005).

In most African countries, ICT policies should be adopted to help the countries to achieve good governance. Currently, they are seen as a practical tool to make, for instance, health, education, and other crucial and basic services accessible to everyone. In developing countries such as those in Africa, ICT policies are also considered integral parts of the larger development (economic) policy-making processes, and they are often crafted with a general goal of applying ICTs for social and economic development. Not only is there a lack of literature on the topic of the role and impact of existing ICT policies in Africa, but the policies are more generic and do not specifically deal with e-Government, in general, and e-Government websites, in particular. African countries need to heed the general argument that any policy should be "flexible, dynamic and responsive to changing circumstances" (Rowlands, 1996, p. 4). In other words, existing ICT policies need to be adapted to, among others, e-Government and other relevant areas of their applications.

An e-Government initiative which encourages citizens' participation in government activities does not only act as participatory tools through which citizens can contribute actively in government but could also bolster the core notion of democracy. Therefore, African countries need to create awareness among their citizens through literacy campaigns to make them aware of the benefits of e-Government services. Creating awareness is not enough, though. African countries and/or international and non-governmental organizations that are assisting them need to invest in telecommunication, broadband, and associated technologies that can support a robust e-Government infrastructure. They also need to invest in human capital needed to maintain ICT infrastructure to implement e-Government services and websites. In addition, African countries need to adopt a bottom-up approach in the implementation of e-Government services and websites. In other words, they need to encourage local governments to have a presence, perhaps in the form of a local e-Government website, followed by integration at the provincial, state, national, and regional levels (Heeks, 2002).

Finally, as Roy (2007) stated, "It is not difficult to succumb to cynicism or pessimism (or both) when envisioning e-Government's prospects in the poorest regions of the world, notably Sub-Saharan Africa" (p. 329). Critics of the efforts being made to develop and implement e-Government services by African countries should look at India and other East Asian countries for examples of how technology, more specifically the internet, could be a catalyst for the countries' overall development, poverty reduction, and maintenance of democratic societies. It is true that most African countries face many challenges. However, when it comes to information and communication technologies, in general, and eGovernment, in particular, there are encouraging signs.

\subsection{Future work}

An e-Government ranking is as good as the methods, procedures, and frameworks used to produce it. Despite their wider use, some of the current procedures (e.g., West, 2007) have their own limitations (Rorissa, Demissie, \& Pardo, 2008). Future work should focus on identifying these limitations and finding ways to remedy them. Also, there needs to be a constant search for better procedures to compute eGovernment indexes and produce rankings of countries with respect to the diffusion and implementation of e-Government services. In addition to studies that look at e-Government services at the national level, specific works that focus on the status of these services at local government levels, such as the one by Olphert and Damodaran (2007), will help paint a more complete picture. It should also be noted that any analysis of e-Government services and computation of indexes for ranking purposes, based on a single run of the websites such as this work, is just a snapshot of what is likely to change through time, as the websites evolve with respect to their level of e-Government development and other important features. Therefore, a true picture will only be obtained if regular analyses are conducted over a reasonably longer period. Thus, it is recommended that future researchers conduct a longitudinal analysis of relevant websites, similar to those by West (2007) and the United Nations (2003, 2004, 2005, \& 2008). To fully understand the role and impact of existing ICT policies in Africa in the development of e-Government and associated services, it is believed that further research needs to be conducted as well.

\section{Acknowledgements}

We would like to thank Anne L. Dearing, Assistant Professor of English, Hudson Valley Community College in Troy, New York, for her editing and two graduate students for their help in coding and data analyses.

\section{References}

Adam, L. (1997). Content and the web for African development. Journal of Information Science, 23(1), 91-97.

Adam, L., \& Wood, F. (1999). An investigation of the impact of information and communication technologies in sub-Saharan Africa. Journal of Information Science, 25(4), 307-318.

Affisco, J., \& Soliman, K. (2006). E-government: A strategic operations management framework for service delivery. Business Process Management Journal, 12(1), $13-21$.

Al-adawi, Z., Yousafzai, S., \& Pallister, J. (2005). Conceptual model of citizen adoption of e-Government. The Second International Conference on Innovations in Information Technology. Retrieved February 20, 2008, from http://www.it-innovations.ae/ iit005/proceedings/articles/G_6_IIT05-Al-Adawi.pdf

Anzinger, G. (2003). African governments on the WWW. Retrieved March 25, 2008, from http://www.gksoft.com/govt/en/africa.html

Carter, M. R., \& May, J. (2001). One kind of freedom: Poverty dynamics in post apartheid South Africa. World Development, 29(12), 1987-2006.

Chango, M. (2007). Challenges to e-Government in Africa south of Sahara: A critical view, and provisional notes for a research agenda. In T. Janowski, \& T. A. Pardo (Eds.), Proceedings of the 1st International Conference on Theory and Practice of Electronic Governance, ICEGOV 2007 (Macao, China, December 10-13, 2007) (pp. 384-393). New York: ACM.

Cohen, J. (1960). A coefficient of agreement for nominal scales. Educational and Psychological Measurement, 20, 37-46.

Gebremichael, M., \& Jackson, J. (2006). Bridging the gap in sub-Saharan Africa: A holistic look at information poverty and the region's digital divide. Government Information Quarterly, 23, 267-280.

Gil-Garcia, J. R. (2005). Exploring the success factors of state website functionality: An empirical investigation. Proceedings of the International Conference on Digital Government Research (Atlanta, Georgia, 2005) (pp. 121-130). Atlanta, Georgia: Digital Government Society of North America.

Gillwald, A., Esselaar, S., Burton, P., \& Stavrou, A. (2005). Towards an e-index for South Africa: Measuring household and individual access and usage of ICT. Retrieved May 20 2009, from http://www.ictportal.org.za/documents/d00018/SA_e-index_2004.pdf

Heeks, R. (2002). E-Government in Africa: Promise and practice. Information Polity: The International Journal of Government \& Democracy in the Information Age, 7(2/3), 97-114.

Ifinedo, P. (2005). Measuring Africa's e-readiness in the global networked economy: A nine-country data analysis. International Journal of Education and Development Using Information and Communication Technology, 1(1), 53-71.

InfoDev, (2002). The e-Government handbook for developing countries. Washington, DC: The World Bank. Retrieved May 1, 2009, from http://unpan1.un.org/intradoc/ groups/public/documents/apcity/unpan007462.pdf

Internet World Stats, (2009). World Internet users and population stats. Retrieved June 10, 2009, from http://www.internetworldstats.com/stats.htm 
Ke, W., \& Wei, K. K. (2004). Successful e-Government in Singapore. Communications of the ACM, 47(6), 95-99.

Layne, K., \& Lee, J. (2001). Developing fully functional e-Government: A four stage model. Government Information Quarterly, 18(2), 122-136.

Lee, S. M., Tan, X., \& Trimi, S. (2005). Current practices of leading e-Government countries. Communications of the ACM, 48(10), 99-104.

Maumbe, B. M., Owei, V., \& Alexander, H. (2008). Questioning the pace and pathway of e-Government development in Africa: A case study of South Africa's Cape Gateway project. Government Information Quarterly, 25, 757-777.

Moon, M. J. (2002). The evolution of e-Government among municipalities: Rhetoric or reality? Public Administration Review, 62(4), 424-433.

Mwangi, W. (2006). The social relations of e-Government diffusion in developing countries: The case of Rwanda. Proceedings of the 2006 International Conference on Digital Government Research (San Diego, California, May 21-24, 2006) (pp. 199-208). New York: ACM.

Neuendorf, K. A. (2002). The content analysis guidebook Thousand Oaks, CA: Sage Publications.

Odedra, M., Lawrie, M., Bennett, M., \& Goodman, S. (1993). Sub-Saharan Africa: A technological desert. Communications of the ACM, 36(2), 25-29.

Olphert, W., \& Damodaran, L. (2007). An evaluation of the information content of loca authority websites in the UK using citizen-based scenarios. Library and Information Research, 31(98), 45-60.

Rorissa, A., Demissie, D., \& Pardo, T. A. (2008). Toward a common framework for computing e-government index. In T. Janowski \& T. A. Pardo (Eds.), Proceedings of the 2nd international Conference on theory and Practice of Electronic Governance (Cairo, Egypt, December 1-4, 2008) (pp. 411-416). New York, NY: ACM.

Rowlands, I. (1996). Understanding information policy: Concepts, frameworks and research tools. Journal of Information Science, 22(1), 13-25.

Roy, J. (2007). E-government, democratic governance and integrative prospects for developing countries: The case for a globally federated architecture. In Latif AlHakim (Ed.), Global e-Government: Theory, applications and benchmarking (pp. 320-339). Hershey, PA: Idea Group Publishing.

Schuppan, T. (2009). E-Government in developing countries: Experiences from subSaharan Africa. Government Information Quarterly, 26, 118-127.

Torres, L., Pina, V., \& Acerete, B. (2005). E-government developments on delivering public services among EU cities. Government Information Quarterly, 22(2), 217-238.

United Nations, (2003). UN global e-Government survey. Retrieved February 20, 2008 from http://unpan1.un.org/intradoc/groups/public/documents/un/unpan016066. pdf

United Nations, (2004). United Nations global e-Government readiness report. Retrieved February 20, 2008, from http://unpan1.un.org/intradoc/groups/public/ documents/UN/UNPAN019207.pdf
United Nations, (2005). United Nations global e-Government readiness report. Retrieved February 20, 2008, from http://unpan1.un.org/intradoc/groups/public/ documents/un/unpan021888.pdf

United Nations, (2008). United Nations e-Government survey 2008: From eGovernment to connected governance. Retrieved September 2, 2008, from http:// unpan1.un.org/intradoc/groups/public/documents/UN/UNPAN028607.pdf

United Nations Division for Public Economics and Public Administration (UNDPEPA), (2002). Benchmarking e-Government: A global perspective. Retrieved June 19, 2008, from http://aps.vlaanderen.be/straplan/vindplaatsen/benchmarking-e-government. pdf

Weinberg, S. L., \& Goldberg, K. P. (1990). Statistics for the behavioral sciences New York: Cambridge University Press.

West, D. M. (2004). e-Government and the transformation of service delivery and citizen attitudes. Public Administration Review, 64(1), 15-27.

West, D. M. (2007). Global e-Government. Retrieved February 20, 2008, from http:// www.insidepolitics.org/egovt07int.pdf

Abebe Rorissa is an Assistant Professor at the Department of Information Studies, University at Albany, SUNY. He has over 21 years of experience working in four countries and consulted for academic institutions, national governments, and international organizations on information and communication technologies as well as information organization. Dr. Rorissa is widely published and his works appear in the Journal of the American Society for Information Science \& Technology and Information Processing and Management. His research interests include adoption, use, \& impact of information and communication technologies (ICTs); multimedia information organization and retrieval; and human information behavior. Dr. Rorissa served on program committees of international conferences and edited some proceedings.

Dawit Demissie is a Ph.D candidate in the Informatics (INF) PhD program at the College of Computing and Information, University at Albany, State University of New York. He received a BA in Computer/Information Science from State University of New York at Oswego, and an MS in Telecommunications \& Network Management from Syracuse University. Before joining the INF PhD program, he had been a Software Engineer in Test and prior to that, he had served as a System Consultant and Information Technology Specialist at various organizations in New York. He also had been an Instructor at State University of New York (SUNY) at Albany, Hudson Valley Community College, Bryant \& Stratton College, Syracuse University, and SUNY Oswego. He has published and presented in major journals and conference proceedings, and his research interests include empirical testing of models and theories of information technology, Human computer Interaction, e-Government index computation, and knowledge management. 